\title{
MEMOIRS
}

\section{WILLIAM PEYTON PHELPS}

WE record with the greatest regret the death on 14 March 1942, a few weeks before his 77 th birthday, of WILL I AM PEY TON,PHELPS, M.A., a Fellow and Past Ptesident of the Institute. He was unmarried but leaves a sister surviving him, and to her and other. relatives the members will extend their deep sympathy. Few men can have more richly deserved, or more fully received; the admiration, gratitude and affection of their fellow-workers.

Phelps came of an old family. and was devoted to it. His father was Colonel Peyton Phelps, Bombay Royal Engineers, and William was born at Kurrachee on 22 April 186.5 . He remained in India until the age of 5 , and had a clear recollection of life in that country. He then carne home, with some of his brothers and sisters, to live with his grandfather and aunts in Devon. Later the family left India and Colonel Phelps was appointed Commanding Officer of Spike Island (Cork Harbour), then a prison and fortress under the British Crown, and there William spent his early boyhood. Finally they resided in Norwood, and William attended the City of London School. In $x 88_{3}$ he went up to Cambridge and entered Gonville and Caius College to read for the mathematical tripos. It was unnecessary, and perhaps foreign to his mind and temperament, to sacrifice everything else to becoming a wrangler; so while working steadily and conscientiously he left himself time to enter into the life of the College and to get the full human value of his University life. By way of exercise and sport he both rode and rowed: no doubt his love of horses and horse-riding went back to. his Irish days, while at Cambridge he rowed in the College Trial Eights. $\mathrm{He}$ was also a keen Volunteer with a high sense of discipline. He graduated with mathematical honours in 1886 when he was placed sixth in the list of junior optimes, and he proceeded to M.A. in I89o.

With a military ancestry and a boyhood spent in military surroundings it was natural that his heart should be in the army, and he was at one time intended for a military career. But this proved to be impracticable, and the bot fell on a younger son, Arthur, who served with distinction in the Boer War and the War of 1914-18 and retired with the rank of Brigadier-General. So William had to find another career, and to the great benefit of life assurance and the actuarial profession he selected* this walk of life, in which he so greatly distinguished himself. After coming down from Cambridge, in 1887 he obtained a clerkship in the Crown Life

* This was on the advice of a friend of the family, Mr J. Clifford Hopkinson, M.A., at one time Assistant Secretaty of the Institute. 


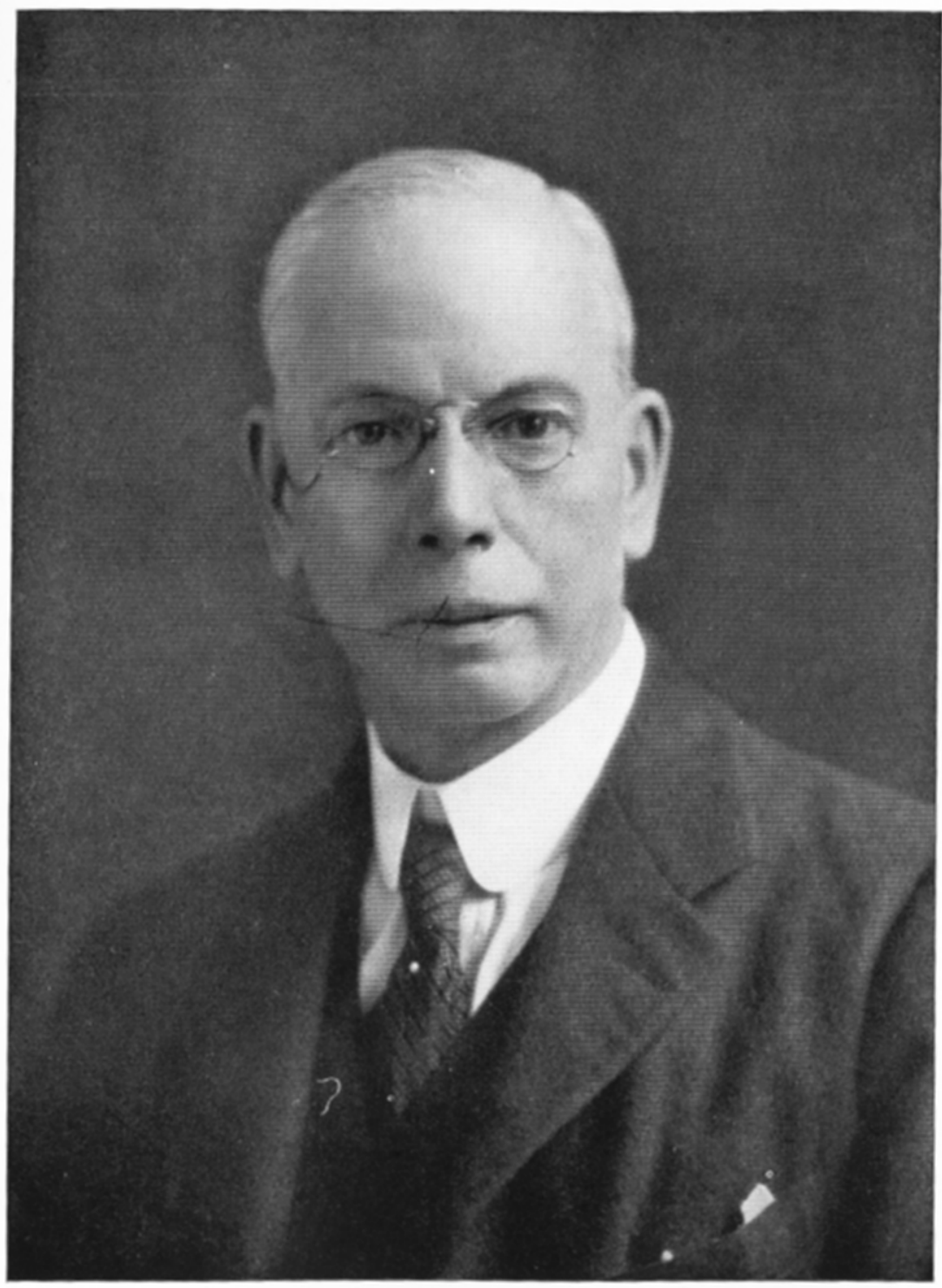

William Peyton Phelps 


\section{Memoirs}

Office, afterwards absorbed in the Law Union Office, and in the following year he transferred to the Equity and Law Life Assurance Society, with which he remained for the whole of his professional life. It must have been about a year earlier that another eminent actuary, $\mathrm{Mr} \mathrm{D}$. C. Fraser, M.A., who was partly contemporary with Phelps at Cambridge, similarly entered a life office after taking honours in the tripos. At that time it was comparatively rare for mathematical honours men to take up actuarial work, but what was then a small trickle has since become a steady flow, to the great advantage of the profession.

Phelps's connexion with the Equity and Law, begun thus early, was to endure for 53 years and to constitute his main life work. He entered the Institute as a student in 1887 , and passed the Part I Examination in the same year and the Intermediate in 1890 , and the writer likes to remember that he worked for and passed these examinations in company with Phelps and in this way began a lifelong and very dear friendship. He passed the Final a year later, in 1891 , a year ahead of the writer. He read for the Intermediate and Final with G. F. Hardy; the two had much in common, and master and pupil became intimate friends. In 1894 Phelps was appointed Assistant Actuary of the Equity and Law, and in 1904, when his chief, Mr A. F. Burridge, F.I.A., died, succeeded him as principal officer. He held this post until 1930, when he retired at the age of 65 . It was under his managership that in 1910-1 I the office acquired $99 \%$ of the capital of the National Reversionary Interest Society and the whole of the capital of the Law Reversionary Interest Society; by this means he both extended the Society's connexions and enlarged its already very considerable holdings of remunerative reversionary investments. He was devoted to his office, and by his vigorous yet conservative management enlarged and revivified it and left it in a highly prosperous condition, if not in the midstream of competitive business. The devoted service of a lifetime was fittingly recognized by his elevation to the Board on his retirement, and he continued to serve the office in this way until 1941, when he retired from the Board.

In 1903 Phelps took part in the formation of the Gallio Club,* which has since become an important body, but at the outset was limited to a few of the younger and (as they confidently hoped) rising actuaries, who dined together after the Institute Sessional meetings, and who, theoretically at least, 'cared for none of these things' for the rest of the evening. In 1904 he received the distinction of election to that very close corporation, the Actuaries' Club, of which he was Chairman in 1917-19. He had naturally become prominent in the Institute. Though he worked very hard for his office he was extremely methodical and

- For an account of its formation vide D. C. Fraser's Mernoir of Ralph Todhunter, Y.I.A. Vol, LvII, p. 342 . 
precise, and like so many busy men he was able to find time for much work for the benefit of the profession and the life assurance business. He served on many occasions as an Examiner, and in 1904 he for the first time joined the Council, on which he served for a total of 25 years, viz. continuously from 1904 to 1930 with the single exception of the year 1916-17, during which he was Chairman of the Life Offices' Association. He discharged the onerous duties of Joint Honorary Secretary to the Institute for the four years 1908-II, and was one of its Vice-Presidents in the four following years, 1912-15, and Treasurer for the years 1918-19. At the annual meeting of the Institute held on 12 June 1922 he was elected President for the two following years, and thus became the head of the profession for which he had done so much. This was at once the highest honour that he could receive from his colleagues and the culmination of his work, which thus ranged over all the principal offices in the Institute, excepting those of Librarian and Editor of the fournal. In his presidential address (F.I.A. Vol. LIV, p. I), to quote his own words, he "endeavoured to review briefly some of the more important problems and developments of general actuarial interest that have recently presented themselves'. This address was of great value and interest, admirably constructed and composed in direct and limpid English, reminding one irresistibly of Buffon's dictum, 'Le style est l'homme même'. The subjects dealt with included Continuous Mortality Investigation, then in its infancy; the first valuations of Approved Societies for National Health Insurance; Social Services, including Superannuation Schemes; National Statistics; and current problems relating to Industrial Life Assurance Business. In his treatment of these he revealed those qualities of exact information, clear insight and good judgment which characterized the man and his work. The same qualities were evident in the remarks which he made from the Chair, and at other times, in the discussion of papers read at the sessional meetings, which he attended with great regularity.

Staple Inn cannot need any tangible memorial of one so closely identified with it; yet as it happens, owing to his own generosity, one already exists there. Phelps wanted to do something to mark his attachment to the Institute, and he had long thought that the very ordinary Council table and chairs were unworthy of their ancient surroundings. So in 1932 (see f.I.A. Vol. LXIV, p. I2) he presented the Institute with a fine refectory table specially made to an old Elizabethan design, with a set of chairs of Cromwellian style bearing the old insignia of Staple Inn stamped on their leather backs. It was a munificent and highly appreciated gift, presented in a spirit characteristic of the donor.

On the administrative side of the business Phelps's services were also outstanding. He was influential in the counsels of the Life Offices' Association and was its Chairman in 1916-18. With many differing opinions, and possible conflicting interests, to be harmonized, the 


\section{Memoirs}

Chairman's task is not always an easy one, and it is at all times onerous. Phelps's accurate knowledge, his impressive appearance, and his impartiality, tact and invariable good humour combined to make him a most successful Chairman, who was able to smooth away difficulties and secure the goodwill and co-operation of all.

So far as can be traced his written. work was confined to his Presi dential Address, Memoirs of S. G. Warner, F.I.A. [F,I.A. Vol. $\mathrm{sx}$, p. I (rg29)], and George King, F.I.A., F.F.A. [f.I.A. Vol, Lxill, p. 528 (1932)], and a paper entitled 'Notes on some legal matters in relation to life policies', which he read before the Insurance Institute of Yorkshire in 1902. He did not court publicity, but preferred to devote his energies to the quiet but invaluable services which he gave so freely to the profession.

His public services must not be forgotten. During his chairmanship of the Life Offices' Association he went to Paris as a member of an official party concerned with the consideration of draft clauses relating to life assurance, to be eventually embodied in a Treaty of Peace. In $1922-4$, i.e. during the period of his presidency, he was a member of the Council of the Royal Patriotic Fund, whose meetings he attended regularly. In r924 the Board of Trade appointed a Committee-generally known as the Clauson Committee-to consider amendments to the Assurance Companies Act, I909, and the actuarial profession was invited to nominate a member, in addition to $\mathrm{Mr} \mathrm{S.} \mathrm{H.} \mathrm{J.} \mathrm{W.} \mathrm{Allin,} \mathrm{C.B.E.,}$ F.I.A., one of the official members, and Mr H. M. Trouncer, M.A., F.I.A., representing the Life Offices' Association. The then President of the Institute, Mr A. D. Besant, who would have been the natural choice, felt unable to act on this Committee, as he was at the time serving as a member of a Royal Commission [National Health Insurance]; and the President of the sister society, the Faculty of Actuaries in Scotland, felt unable to undertake duties involving numerous and frequent sittings in London. In these circumstances the profession naturally turned to Phelps as ex-President of the Institute, and he accepted the office. The Committee sat for over a year and held seventy-five meetings, at thirty of which evidence was heard, often based on lengthy printed heads of evidence requiring careful preliminary consideration. It is safe to say that Phelps was absent from few of the meetings, and that the Committee's valuable report and the draft Bill included in it owe much to his knowledge and experience and his conscientious work on the Committee.

Phelps was a loyal son of the Church of England, and it was characteristic of his willingness for service that, after his retirement, he acted as Honorary Treasurer of Christ Church, Chelsea, keeping the extensive accounts in a fair and clerkly hand which might have been the envy of a professional accountant.

In personal appearance Phelps was a tall and impressive figure-he 
stood about $6 \mathrm{ft} .3$ ins.-with a slight scholarly stoop of the shoulders in recent years. He had a somewhat deliberate voice and a natural dignity of manner, and at the same time a charm and an evident friendliness which put everyone at ease and made him singularly attractive. He was courteous and friendly to all, whatever their station in life, though he could deal effectively with any presumption or impertinence. His mind was deliberative and accurate rather than specially quick. Thus he read rather slowly and in Bacon's words 'chewed and digested' as he read 'not to contradict and confute; nor to believe and take for granted; nor to find talk and discourse; but to weigh and consider'. So his mind was well stored, his information precise and accurate, and his judgment invariably sound. In every detail of his life he was precise and orderly, so that in spite of the great amount of work he got through he was never hurried or perturbed, and he was never too busy to spare time to give help and valuable counsel to others. He lived alone, and while he was the soul of hospitality and entertained considerably in a modest and intimate way he had considerable leisure time to himself. Much of this he occupied with reading, mostly of the solid variety, and with classical music of which he was very fond. He himself played the piano, and he was particularly happy in playing duets with his sister Rachel, an accomplished musician. He took a keen interest in men, places and things, and he travelled widely, rarely missing an International Actuarial Congress. $\mathrm{He}$ had a most affectionate and lovable nature and a great gift of friendship; his broad culture and his wide sphere of interests combined with his unselfish thought for others made him a charming companion and a most loyal friend. He had the liberal mind which deviseth liberal things, and was generous also in his judgment and appreciation of other men's work; he had also a saving sense of humour and a great capacity for the enjoyment of things both small and great. His fine character summed up the full meaning of the word 'integrity': his own standard was of the highest, and he could not tolerate anything mean or tricky in others. Perhaps if one had to sum up Phelps in a word it might be 'straightforward': straight as a die in his character, direct in his approach to his work and any practical problem, undeviating in his purpose, and uninterrupted in his progress to the head of his profession and his office.

We are indebted to $\mathrm{Mr}$ Besant for pointing out how aptly Phelps himself was described in the closing words of his own charming memoir of Warner: 'He was a gifted and kindly soul with high ideals; his life was full of service to others, and he will ever live in the memories of those who knew him as one of the best beloved of his generation', though this he hardly realized, owing to his great natural modesty. The world is a better place for his having lived in it, and the poorer for his passing.

G. $\mathbf{3 . 2 .}$ 


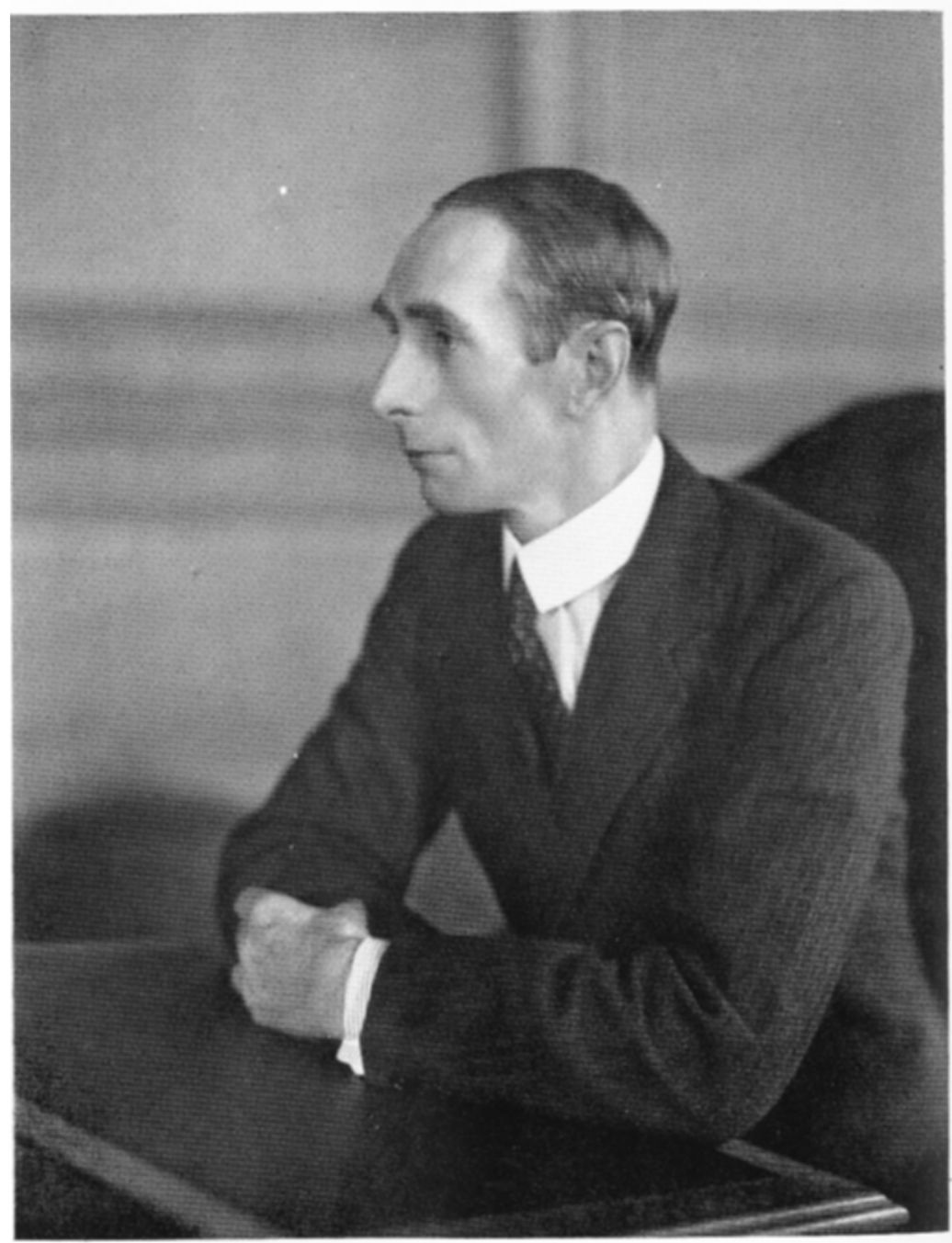

ALBERT EDWARD KING. 